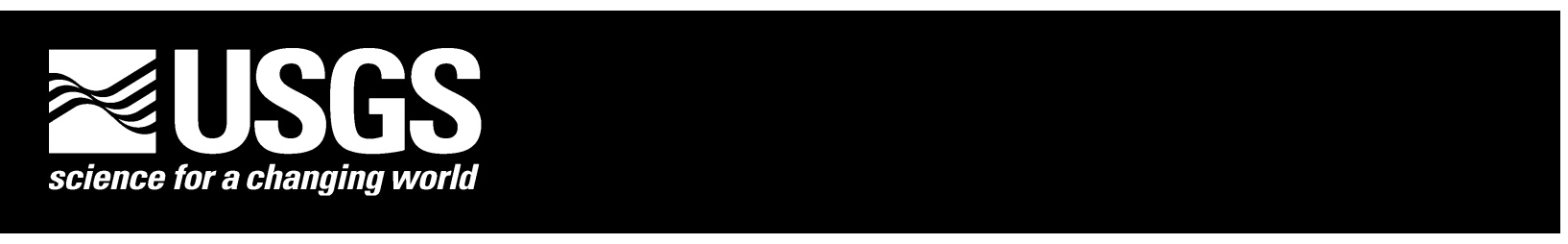

U.S. DEPARTMENT OF THE INTERIOR

U.S. GEOLOGICAL SURVEY

\title{
GROUND-MAGNETIC STUDIES OF THE AMARGOSA DESERT REGION, CALIFORNIA AND NEVADA
}

Richard J. Blakely, John W. Hillhouse, and Robert L. Morin

U.S. Geological Survey, 345 Middlefield Road, Menlo Park, CA 94025

Open-File Report 2005-1132

\section{5}

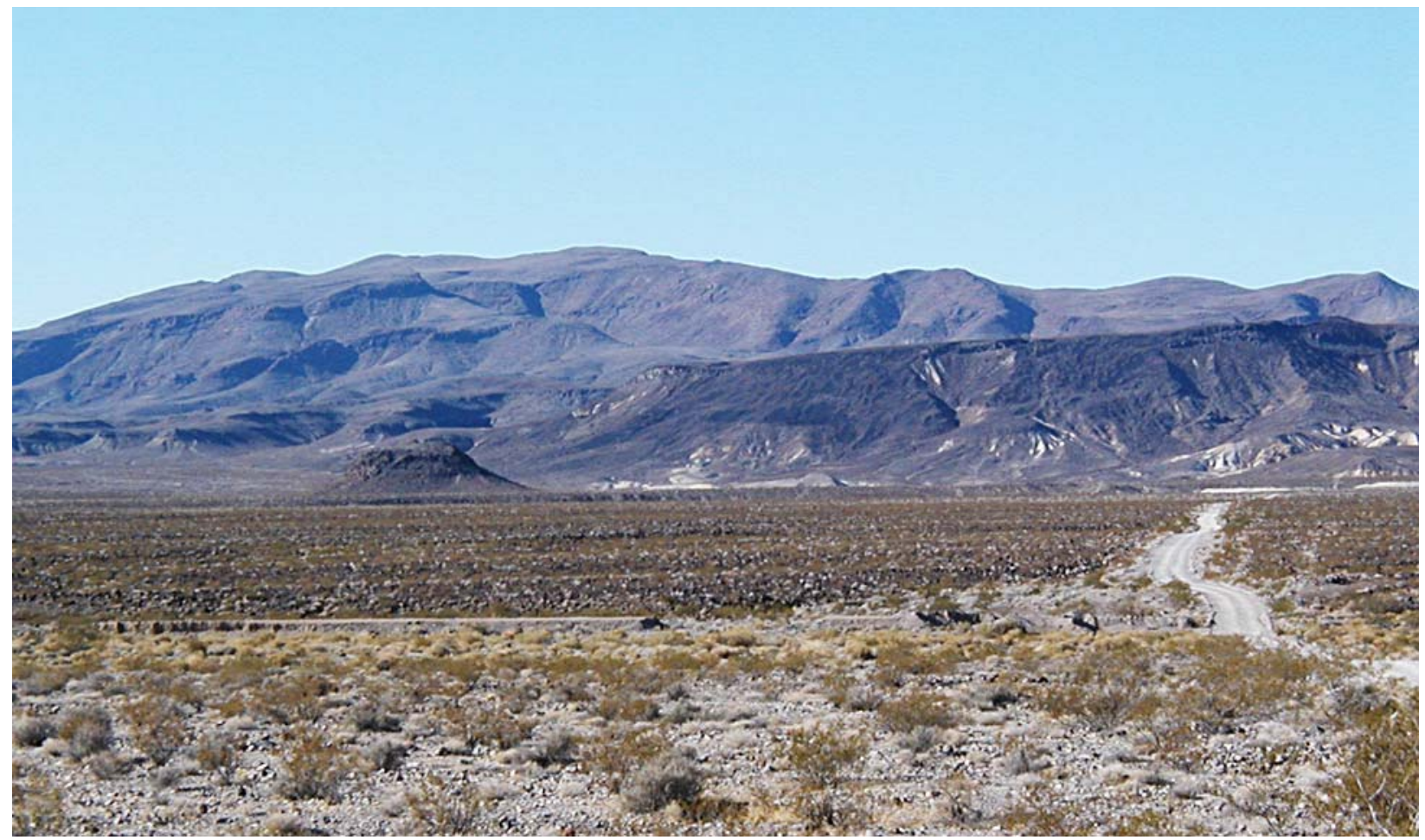

This report is preliminary and has not been reviewed for conformity with U.S. Geological Survey editorial standards or with the North American Stratigraphic Code. Any use of trade, firm, or product names is for descriptive purposes only and does not imply endorsement by the U.S. Government. 


\title{
GROUND-MAGNETIC STUDIES OF THE AMARGOSA DESERT REGION, CALIFORNIA AND NEVADA
}

Richard J. Blakely, John W. Hillhouse, and Robert L. Morin

\begin{abstract}
High-resolution aeromagnetic surveys of the Amargosa Desert region, California and Nevada, exhibit a diverse array of magnetic anomalies reflecting a wide range of mid- and upper-crustal lithologies. In most cases, these anomalies can be interpreted in terms of exposed rocks and sedimentary deposits. More difficult to explain are linear magnetic anomalies situated over lithologies that typically have very low magnetizations. Aeromagnetic anomalies are observed, for example, over thick sections of Quaternary alluvial deposits and spring deposits associated with past or modern ground-water discharge in Ash Meadows, Pahrump Valley, and Furnace Creek Wash. Such deposits are typically considered nonmagnetic. To help determine the source of these aeromagnetic anomalies, we conducted ground-magnetic studies at five areas: near Death Valley Junction, at Point of Rocks Spring, at Devils Hole, at Fairbanks Spring, and near Travertine Springs. Depth-to-source calculations show that the sources of these anomalies lie within the Tertiary and Quaternary sedimentary section. We conclude that they are caused by discrete volcanic units lying above the pre-Tertiary basement. At Death Valley Junction and Travertine Springs, these concealed volcanic units are probably part of the Miocene Death Valley volcanic field exposed in the nearby Greenwater Range and Black Mountains. The linear nature of the aeromagnetic anomalies suggests that these concealed volcanic rocks are bounded and offset by near-surface faults.
\end{abstract}

Cover photo: Greenwater Range, Death Valley National Park. View is to west from Ash Meadows. Note gently dipping lava flows and interbedded tuffaceous beds, part of the Death Valley volcanic field. 


\section{INTRODUCTION}

High-resolution aeromagnetic surveys of the Amargosa Desert region (Figs. 1 and 2) exhibit a diverse array of magnetic anomalies reflecting the wide range of mid- and upper-crustal lithologies in this area. In most cases, the anomalies are easily understood in terms of exposed rocks and deposits. Linear, high-amplitude anomalies in the northern part of Figure 2, for example, are caused largely by exposed, sub-horizontal, strongly magnetic layers of Miocene ash-flow tuff and interbedded air-fall tuffs, offset by north-striking normal faults (Workman and others, 2002; Ponce and others, 1995).

More difficult to explain are linear, low-amplitude magnetic anomalies situated over lithologies that typically have very low magnetizations. In the Funeral Mountains, for example, a series of north- to north-northeast-striking anomalies cross exposures of pre-Tertiary quartzite and carbonate rocks (Fig. 2, longitude $116^{\circ} 45^{\prime} \mathrm{W}$, latitude $36^{\circ} 39^{\prime} \mathrm{N}$ ). Early interpretations of these aeromagnetic anomalies (Blakely and others, 2000a, 2000b) suggested that they are caused by secondary mineralization along near-surface faults, and, because the anomalies are on strike with important springs near Furnace Creek, it was further speculated by the same authors that these faults may influence ground-water flow into Death Valley National Park. More recent groundmagnetic studies (Hillhouse and Morin, 2003) have shown, however, that these low-amplitude bedrock anomalies are actually caused by steeply dipping, weakly magnetic beds within the late Proterozoic Stirling Quartzite, and thus are not related directly to ground-water flow.

Subtle aeromagnetic anomalies are also observed over thick alluvial deposits in Ash Meadows, Pahrump Valley, and Furnace Creek Wash. The sources of these anomalies are also problematic because Quaternary alluvium is typically considered nonmagnetic. In Pahrump Valley, magnetic anomalies over alluvium are spatially associated with the State Line fault (Blakely and others, 2000a), suggesting that faulted contacts in or beneath the alluvium may be responsible for the anomalies. Displacement along the fault may have juxtaposed rocks with contrasting magnetic properties, or secondary mineralization may have deposited magnetic minerals along the faulted contacts. Other explanations are possible, of course. The magnetic anomalies in Pahrump Valley, for example, also lie over the deepest parts of the modern-day basin, presumably marking its long-term depocenter. Thus, near-surface magnetic anomalies may originate from magnetic minerals and detritus concentrated by fluvial processes along this axis of deposition.

It is important to understand the origin of these alluvial magnetic anomalies. If they are caused by faults, for example, existing high-resolution aeromagnetic anomalies will facilitate mapping the spatial distribution of Quaternary faults otherwise concealed in this region, thus providing an important constraint in understanding ground-water flow into Death Valley. This paper describes ground-magnetic studies in Ash Meadows and Furnace Creek Wash with the purpose of determining the cause of these low-amplitude aeromagnetic anomalies over Quaternary alluvial deposits. 


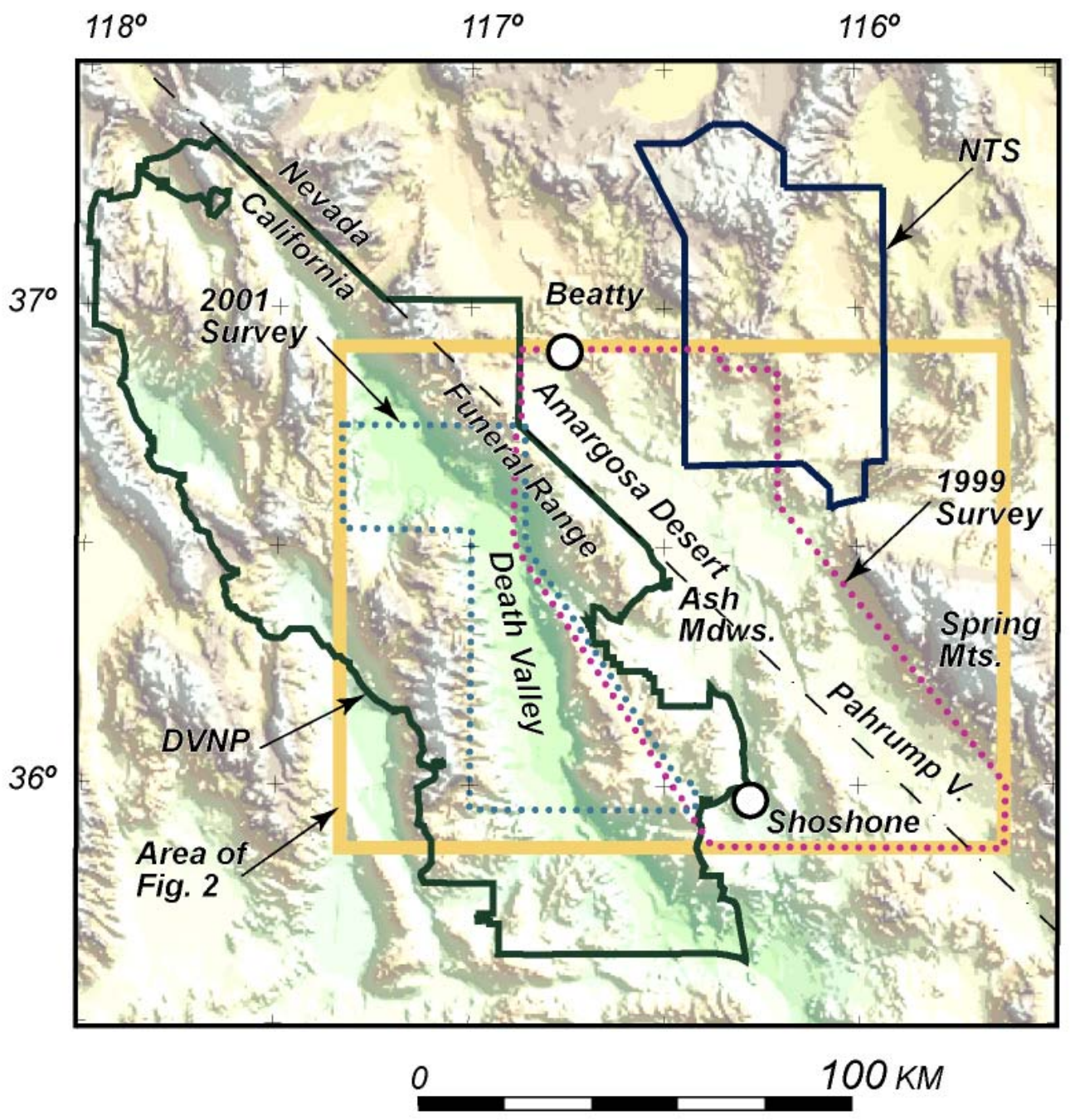

Figure 1.--Location of study area. Dotted lines show boundaries of 1999 (red dots) and 2001 (blue dots) aeromagnetic surveys. 

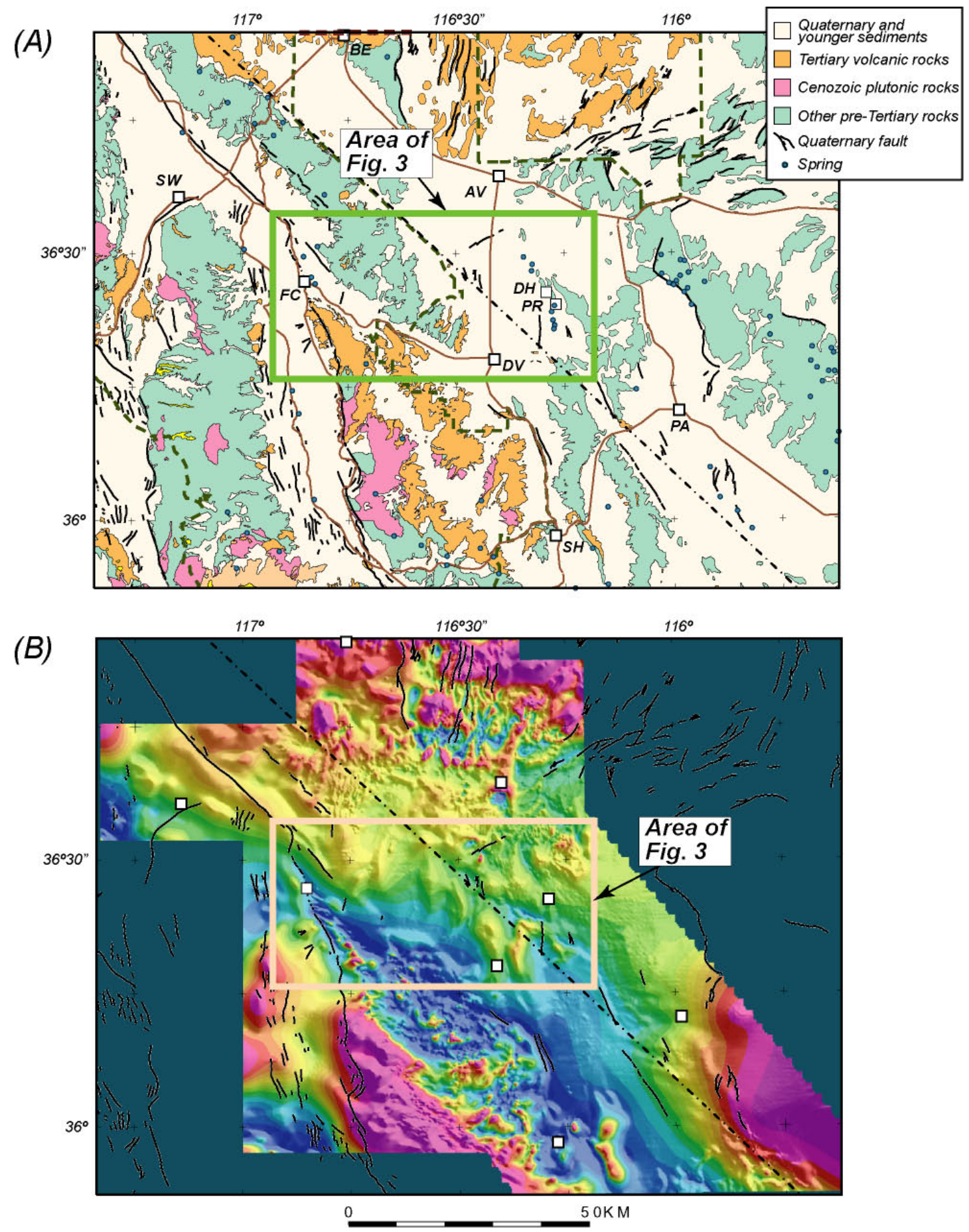

Figure 2.--(A) Generalized geology of the study area, simplified from statewide compilations of California (Jennings, 1977) and Nevada (Stewart and Carlson, 1978). Quaternary faults are from Lienkamper (1985) in California and from Dohrenwend and Moring (1993) in Nevada. Springs are from 1:250,000-scale U.S. Geological Survey topographic maps. AV, Amargosa Valley; BE, Beatty; DH, Devils Hole; DV, Death Valley Junction; FC, Furnace Creek; PA, Pahrump; PR, Point of Rocks; SH, Shoshone; SW, Stovepipe Wells. (B) Map showing aeromagnetic anomalies of the Amargosa region, a combination of the 1999 and 2001 aeromagnetic surveys. Colors indicate intensity of Earth's magnetic field relative to a global reference field. Red colors are typically greater than $50 \mathrm{nT}$, blues colors generally less than $-50 \mathrm{nT}$. 


\section{GEOLOGIC SETTING}

The study area (Fig. 3) lies within the Death Valley extended terrane, a region of diverse geology and dramatic tectonic evolution. Wright and Troxel (1973) viewed the opening of Death Valley and surrounding basins as occurring along normal faults that terminate at relatively shallow depth $(1.5$ to $9 \mathrm{~km}$ ) against gently dipping detachment surfaces. Whereas Wright and Troxel (1973) envisioned relatively small horizontal translations of mountain ranges, others (Stewart, 1983; Hamilton, 1988; Wernicke and others, 1988; Holm and Wernicke, 1990) have proposed more dramatic crustal translations along one or more regionally continuous detachment surfaces. In any case, there is no disagreement that northwest-striking, right-lateral strike-slip faults have played an important role in opening the largest basins of the Death Valley extended terrane. Burchfiel and Stewart (1966) first proposed that central Death Valley developed as a pull-apart basin accommodating strain between the Furnace Creek and Death Valley fault zones, and Wright (1988) proposed that basins beneath Pahrump Valley and Ash Meadows may have opened along right-stepping offsets of the State Line fault zone (Wright, 1988).

Most of the mountain ranges of the study area (Fig. 3) are underlain by Paleozoic and older carbonate (limestone and dolomite) and crystalline rocks (e.g., Workman and others, 2002). Carbonate rocks are believed to be an important aquifer in this part of the Basin and Range (Winograd and Thordarson, 1975; Dettinger, 1989; Laczniak and others, 1996; McKee, 1997). Intervening basins, like Death Valley, Amargosa Desert, and Pahrump Valley, are filled with relatively young sedimentary deposits (Fig. 3), consisting of non-marine sedimentary and volcanic rocks, generally Oligocene and younger in age. They include fluvial conglomerate, sandstone, siltstone, lacustrine claystone and limestone, volcanic ash deposits of various kinds, and local lava flows. The upper parts of the basins typically are covered by Quaternary sediments, mostly alluvial, playa, and eolian deposits (Workman and others, 2002).

The density of basin-fill deposits is sharply lower than the pre-Tertiary rocks that underlie the basins. These contrasting densities are reflected in gravity data as low anomalies over basins and positive anomalies over mountain ranges. By assuming a simple basin-and-range model, gravity anomalies can be mathematically inverted to estimate the three-dimensional shape of the basins (e.g., Jachens and Moring, 1990). An inversion of gravity anomalies from the entire Amargosa Desert region (Blakely and others, 1998) found a structural trough extending northward from the State Line fault, through Ash Meadows, to the Yucca Mountain region. The eastern margin of the Amargosa trough corresponds to a fault (sometimes referred to as the "gravity fault") identified in various studies (Schweickert and Lahren, 1997; Winograd and Thordarson, 1975; Connor and others, 2000). In Ash Meadows, the estimated thickness of Cenozoic deposits generally exceeds $1 \mathrm{~km}$ (Fig 3A) and sometimes exceeds $2.5 \mathrm{~km}$.

Tertiary volcanism also played an important role in the extensional history of the Amargosa Desert region. Miocene ash-flow and air-fall tuffs of the southwestern Nevada volcanic field dominate much of the scenery north of our study area (Fig. 2). West and south of our study area, Miocene lava flows and tuffs of the Death Valley volcanic field are distributed throughout the Greenwater Range and Black Mountains (Workman and others 2002). The Amargosa trough spatially connects these two volcanic complexes. 

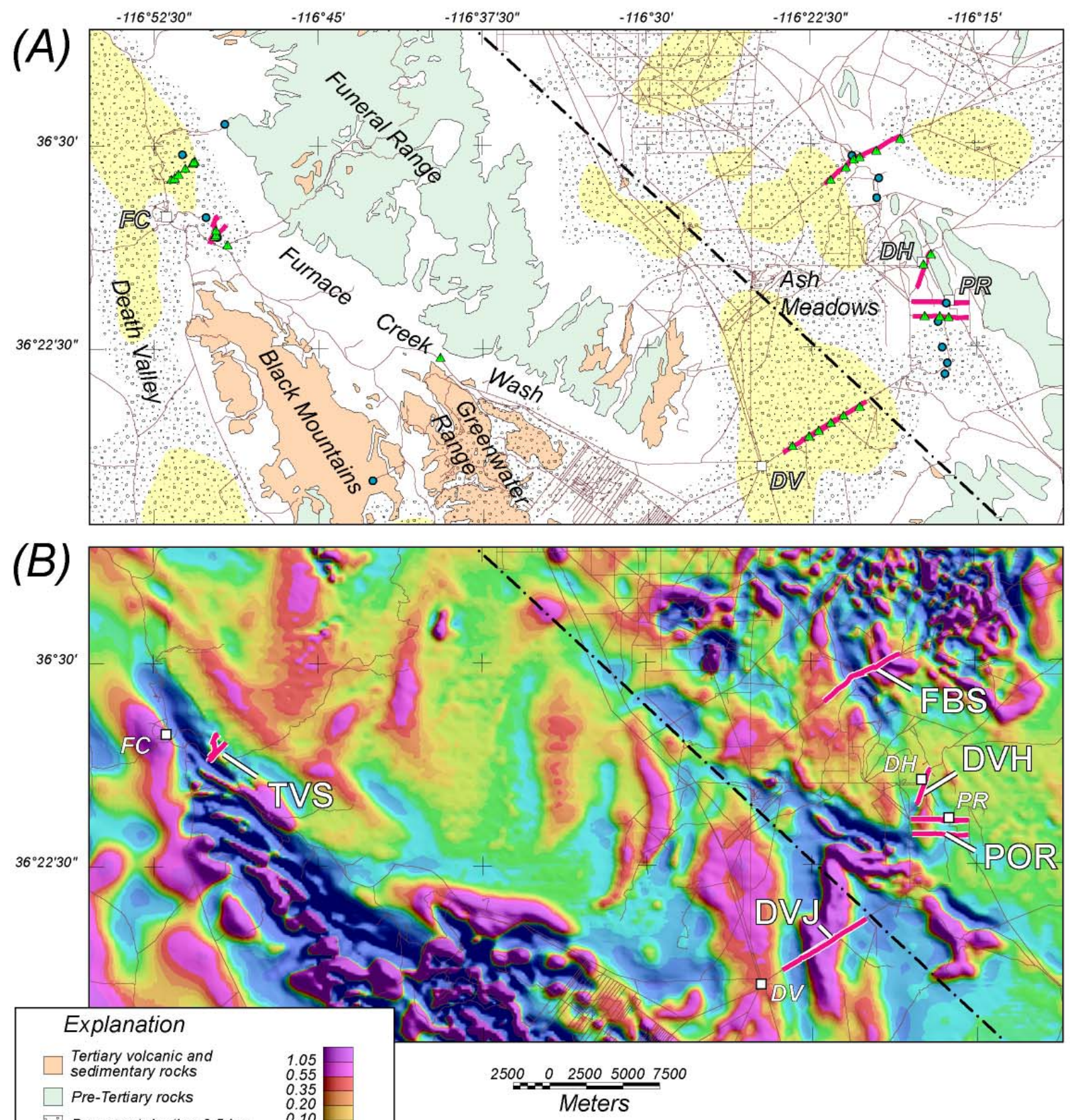

Basement depth $>0.5 \mathrm{~km}$

Basement depth $>1 \mathrm{~km}$

$\triangle$ Susceptibility measurement

- Spring

K Road

Ground-magnetic profile

Figure 3.--Location of ground-magnetic profiles and magnetic susceptibility measurements. (A) Generalized geology of the study area. See Figure $2 \mathrm{~A}$ for sources of data. Basement depths estimated from gravity inversion (Blakely et al., 1998). (B) Aeromagnetic anomalies processed in order to emphasize shallow magnetic sources. DVJ, DVH, FBS, POR, and TVS indicate profiles shown in Figures 5-9. See Figure 2 for description of other labels. 


\section{GROUND-MAGNETIC STUDIES}

Aeromagnetic data collected in 1999 and 2001 reflect this diverse geologic setting. Highamplitude, short-wavelength magnetic anomalies are evident over Tertiary tuffs and basaltic intrusions of the Yucca Mountain area (Fig. 2) and over Tertiary volcanic rocks of the Death Valley volcanic field west of Shoshone (Figs. 2, 3, and cover photo). Aeromagnetic anomalies are relatively subdued in the intervening region, reflecting the low magnetization of pre-Tertiary bedrock and Cenozoic basin-filling deposits. Although subdued, a number of low-amplitude anomalies are evident throughout Ash Meadows and Furnace Creek Wash (Fig. 3). Various explanations are possible. (1) The aeromagnetic anomalies may reflect a non-uniform distribution of magnetic detritus within the Quaternary alluvium, perhaps concentrated by fluvial processes. (2) They may reflect discrete magnetic units now buried by alluvium, probably volcanic rocks. The linear nature of the anomalies may indicate dikes or lava flows truncated by near-surface faults. (3) The anomalies may reflect secondary mineralization along near-surface faults.

To help determine the source of these magnetic anomalies, we conducted ground-magnetic studies at several locations within Ash Meadows and Furnace Creek Wash. Seven groundmagnetic profiles from five areas are described here: across Carson Slough near Death Valley Junction, at Point of Rocks Spring, at Devils Hole, at Fairbanks Spring, and near Travertine Springs (Fig. 3).

Ground-magnetic profiles were conducted on foot with a Geometrics 858 magnetometer system, which includes a cesium-vapor magnetic sensor and real-time GPS navigational equipment. Measurements were made at 1-second intervals while walking at a normal pace. GPS navigation was of high quality due to the lack of tree cover. A stationary base station was established near each ground-magnetic traverse and operated simultaneously to correct for diurnal variations of the earth's magnetic field and external field fluctuations. The base-station sensor was a Geometrics 856 proton-precession magnetometer. Desert conditions are ideal for these types of studies. Some "noise" was observed in all profiles, due to culverts and other metallic objects and due to slightly magnetic road materials. However, the geologic "signal" was many times stronger and generally longer in wavelength, making it relatively easy to distinguish from noise. The following figures that describe individual ground-magnetic profile show both the actual measurements (after correcting for time-varying fields) and a running average. The running average helps to distinguish the geologic signal from the near-surface, short-wavelength noise.

Magnetic susceptibility measurements were also made at numerous locations (Figs. 3 and 4; Table 1) in order to characterize magnetic properties of exposed lithologies.

\section{Depth-to-source calculations}

Where appropriate, we used a graphical approach to estimate the depth to causative magnetic sources. The technique, known as "Peters' method" (Peters, 1949), is based on an important property of magnetic anomalies: The horizontal gradient at the margins of a magnetic anomaly depends on the depth to source; i.e., a shallow magnetic body produces a sharper magnetic anomaly relative to an anomaly caused by the same body at deeper depth. Peters' method is 


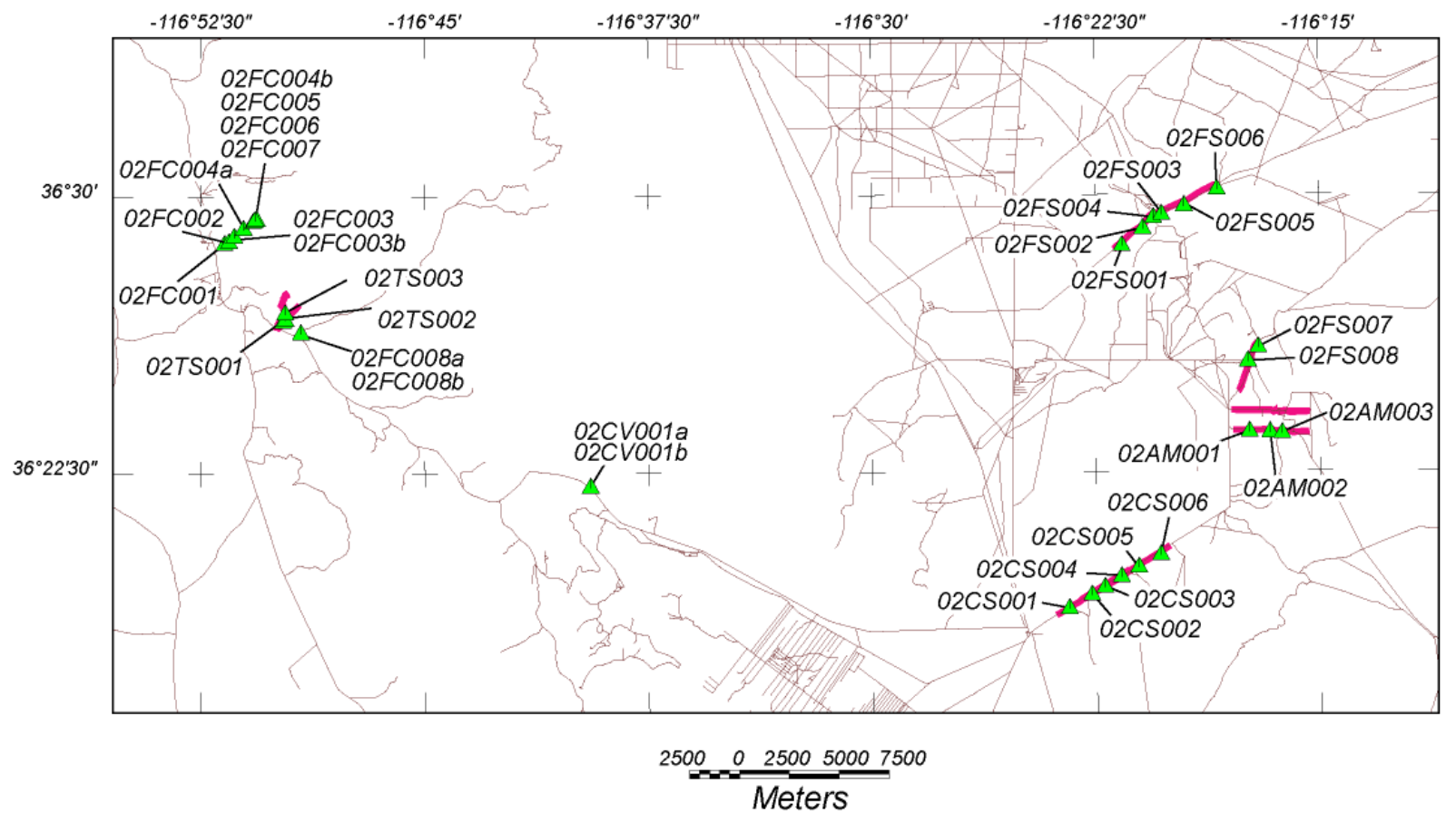

Figure 4.--Location of magnetic susceptibility measurements. See Figure 3 and Table 1. 
Table 1. Magnetic susceptibility measurements in the Amargosa Desert region. Mean and SD are average and standard deviation, respectively, of $\mathrm{N}$ readings, with 1 unit $=0.001 \mathrm{SI}$. See Figures 3 and 4 for site locations.

\begin{tabular}{|c|c|c|c|c|c|c|}
\hline Site & Latitude & Longitude & Mean & $S D$ & $N$ & Comment \\
\hline 02FC001 & 3628.759 & 11651.758 & 0.122 & 0.001 & 10 & Siltstone, Furnace Creek Formation \\
\hline 02FC002 & 3628.813 & 11651.609 & 0.123 & 0.001 & 8 & Siltstone \\
\hline $02 \mathrm{FC} 003 \mathrm{a}$ & 3628.949 & 11651.431 & 0.161 & 0.029 & 8 & $\begin{array}{l}\text { Fanglomerate cobbles; calcium-carbonate } \\
\text { cemented }\end{array}$ \\
\hline 02FC003b & 3628.949 & 11651.431 & 0.194 & 0.001 & 9 & Pebbly matrix \\
\hline $02 \mathrm{FC} 004 \mathrm{a}$ & 3629.164 & 11651.117 & 0.591 & $\$ 0.154$ & 12 & Clayey siltstone \\
\hline $02 \mathrm{FC} 004 \mathrm{~b}$ & 3629.352 & 11650.795 & 0.044 & 0.001 & 8 & Siltstone, laminated \\
\hline 02FC005 & 3629.370 & 11650.760 & 0.069 & 0.000 & 10 & Fine sandstone, tuffaceous(?), white \\
\hline 02FC006 & 3629.417 & 11650.679 & 0.069 & 0.000 & 8 & Siltstone; laminated, green-white \\
\hline 02FC007 & 3629.402 & 11650.732 & 0.035 & 0.001 & 10 & Siltstone, laminated, tuffaceous \\
\hline $02 \mathrm{FC} 008 \mathrm{a}$ & 3626.335 & 11649.199 & 0.249 & 0.070 & 9 & Siltstone, white, resistant \\
\hline 02FC008b & 3626.335 & 11649.199 & 0.693 & 0.739 & 11 & Fanglomerate; above tuffaceous bed \\
\hline $02 C S 001$ & 3618.829 & 11623.476 & 1.730 & 0.044 & 4 & Pebbly surface \\
\hline $02 \mathrm{CS} 002$ & 3619.191 & 11622.721 & 0.514 & 0.008 & 5 & Dried mud \\
\hline $02 \mathrm{CSO} 003$ & 3619.399 & 11622.280 & 0.578 & 0.003 & 4 & Pebbly deposit on playa \\
\hline $02 C 5004$ & 3619.683 & 11621.727 & 0.478 & 0.004 & 4 & Pebbly deposit on playa \\
\hline $02 \mathrm{CS} 005$ & 3619.923 & 11621.156 & 0.896 & 0.010 & 5 & Pebbles on sand \\
\hline $02 \mathrm{CS} 006$ & 3620.274 & 11620.406 & 0.833 & 0.002 & 4 & Pebbles on sand \\
\hline $02 \mathrm{AM} 001$ & 3623.604 & 11617.413 & 0.238 & 0.009 & 6 & Scraped surface; calcium carbonate deposit \\
\hline 02AM002 & 3623.586 & 11616.722 & 0.444 & 0.016 & 7 & Scraped surface; calcium carbonate deposit \\
\hline $02 \mathrm{AM} 003$ & 3623.557 & 11616.322 & 0.038 & 0.001 & 6 & Caliche rubble \\
\hline $02 \mathrm{CV} 001 \mathrm{a}$ & 3622.155 & 11639.503 & 0.100 & 0.005 & 10 & Calcite crack fillings; iron stained (see Fig. 11) \\
\hline 02CV001b & 3622.155 & 11639.503 & 0.066 & 0.002 & 5 & Fanglomerate next to calcite-filled cracks \\
\hline 02FS001 & 3628.655 & 11621.664 & 0.055 & 0.001 & 8 & Siltstone; white and gray \\
\hline $02 \mathrm{FS} 002$ & 3629.118 & 11620.962 & 0.163 & 0.044 & 9 & Siltstone with calcite nodules \\
\hline $02 \mathrm{FS} 003$ & 3629.413 & 11620.602 & 0.269 & 0.037 & 9 & Siltstone; white and tan \\
\hline 02FS004 & 3629.496 & 11620.328 & 0.005 & 0.000 & 6 & Calcareous spring deposit \\
\hline $02 F S 005$ & 3629.730 & 11619.570 & 1.447 & 0.319 & 9 & $\begin{array}{l}\text { Calcite cemented conglomerate; volcanic } \\
\text { and metasedimentary clasts (see Fig. } 8 \text { ) }\end{array}$ \\
\hline $02 F S 006$ & 3630.172 & 11618.463 & 0.860 & 0.105 & 12 & Cobbles on desert pavement \\
\hline 02FS007 & 3625.886 & 11617.110 & 0.045 & 0.001 & 8 & Dolomite at Devils Hole \\
\hline $02 \mathrm{FS} 008$ & 3625.511 & 11617.452 & 0.032 & 0.001 & 5 & Dolomite at Devils Hole \\
\hline 02TS001 & 3626.648 & 11649.798 & 0.127 & 0.006 & 6 & White siltstone in road bed \\
\hline 02TS002 & 3626.707 & 11649.727 & 0.446 & 0.008 & 9 & Fanglomerate; Furnace Creek Formation \\
\hline $02 \mathrm{TS} 003$ & 3626.874 & 11649.727 & 0.263 & 0.017 & 10 & Fanglomerate; Furnace Creek Formation \\
\hline
\end{tabular}

graphical in nature and illustrated in each of the following profile figures: Draw two parallel lines (dotted lines in the figures) with slope equal to one half of the maximum gradient (dashed lines in the figures) of the anomaly, one line tangent to the peak roll-off of the anomaly and the other tangent to the minimum part of the anomaly. The horizontal separation of the two lines is proportional to the depth to the top of the body. The proportionality constant is 1.2 for very thin bodies and 2.0 for very thick bodies. A value of 1.6 is often used, and we have done likewise.

Peters' method assumes that the magnetic anomaly is caused by a two-dimensional body with vertical sides and uniform and nearly vertical magnetization. Although the magnetic anomalies under investigation here are two-dimensional in nature, the other underlying assumptions are less likely to be realized. Several factors in particular may tend to increase our depth estimates. 
First, the direction of magnetization at these latitudes will generally not be vertical, and anomalies caused by bodies with non-vertical magnetization have somewhat gentler gradients than anomalies caused by the same bodies with vertical magnetization. Second, some of the profiles were forced to cross the anomalies at an angle oblique to the strike of the anomaly, which reduces profile gradients. In any case, our depth estimates should be treated as approximate.

\section{Death Valley Junction (profile DVJ)}

A ground-magnetic profile was conducted along the road extending northeast of Death Valley Junction to the California-Nevada state line (Fig. 3, profile DVJ). The profile crosses a flat expanse of Ash Meadows, underlain mostly by fine-grained alluvium of latest Pleistocene to Holocene age. The topographically lowest point of the traverse corresponds with Carson Slough, which drains parts of Ash Meadows southward. The aeromagnetic data show a pronounced linear, north-striking anomaly along Carson Slough (Figs. 2 and 3), but the source of the anomaly must lie at depth because magnetic susceptibility measurements of these finegrained alluvial deposits are very small (Table 1, Fig. 4, sites 02CS001-006).

The ground-magnetic profile (Fig. 5) shows a single anomaly with peak-to-trough amplitude of $90 \mathrm{nT}$, a steep western gradient, and a broad eastern gradient. The location of the groundmagnetic anomaly agrees precisely with the aeromagnetic anomaly. On the basis of the western gradient, we estimate the maximum depth to the magnetic source to be $980 \mathrm{~m}$. As described above, this estimate is probably somewhat overestimated because the profile crossed the anomaly obliquely (Fig. 5). The depth to pre-Tertiary basin exceeds $1 \mathrm{~km}$ beneath the entire profile (Fig. 3), so the source of the anomaly lies deep within the overlying Tertiary and Quaternary section. The amplitude of the ground-magnetic anomaly requires a lithology with significant magnetization, and a volcanic body, perhaps a basaltic lava flow, is our favored interpretation. The linear nature of the anomaly suggests that the horizontal extent of the volcanic unit is fault controlled.

Gravity inversions (Blakely and others, 1998) show that Ash Meadows is underlain by several small sub-basins. The southwestern end of profile DVJ lies over one sub-basin $2.5 \mathrm{~km}$ deep; the northeastern end lies over a second sub-basin about $2.0 \mathrm{~km}$ deep. The intervening saddle rises to about $1.5 \mathrm{~km}$ deep, has a northward strike, and corresponds closely with the position of the aeromagnetic and ground-magnetic anomalies. The gravity inversion assumes, however, that the density of basin-filling deposits remains uniform in all horizontal directions. If sediment densities do in fact vary, the gravity inversion will find erroneous undulations in basin depth. We suggest that the saddle seen in gravity inversions beneath profile DVJ is an artifact caused by the slightly higher density of the faulted volcanic unit at $1 \mathrm{~km}$ depth. 


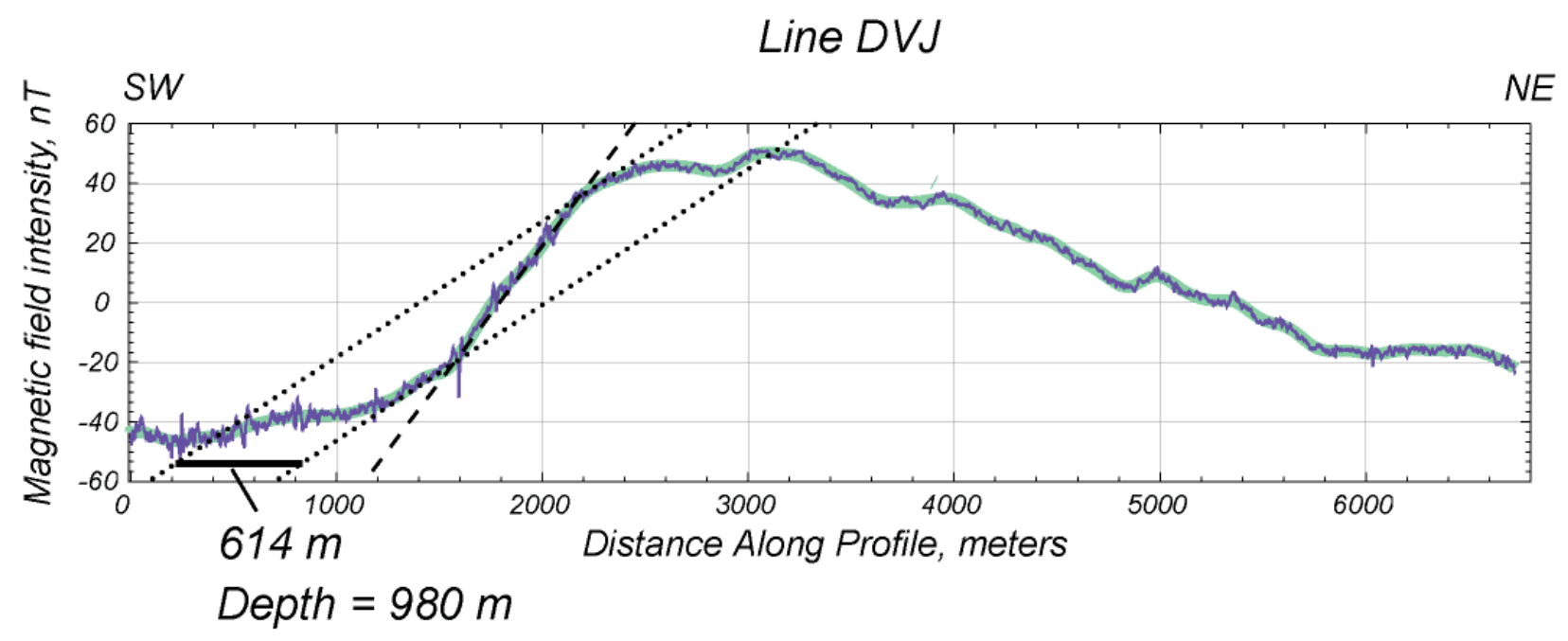

Figure 5.--Ground magnetic profile across aeromagnetic anomaly northeast of Death Valley Junction. See Figure 3 for profile location. Thin purple line indicates observed magnetic field intensity; wide green line is 200-point running average. Dashed and dotted lines were used to estimate depth to magnetic source using Peters' method (1949), as discussed in text. Dashed line indicates maximum slope of magnetic anomaly; dotted lines have slopes equal to 0.5 maximum slope.

\section{Point of Rocks Spring (profiles POR)}

Two ground-magnetic traverses were conducted along east-west dirt roads near Point of Rocks Spring (Fig. 3, profiles POR). The profiles are underlain by alluvium and spring deposits associated with modern and past ground-water discharge. The ground-magnetic profiles cross a small north-striking aeromagnetic anomaly (Fig. 3B) evident in both profiles (Fig. 6). The northern profile displays the anomaly with well-defined gradients and a peak-to-trough amplitude of about $20 \mathrm{nT}$. In the southern profile, the anomaly has an amplitude of about $15 \mathrm{nT}$ and poorly defined margins.

Alluvial and spring deposits at the surface have very low magnetic susceptibilities (Table 1, Fig. 4, sites 02AM001-003) and do not contribute significantly to the magnetic anomaly. On the basis of horizontal gradients of the anomaly, we estimate that the magnetic source lies $390 \mathrm{~m}$ beneath the northern profile and $240 \mathrm{~m}$ beneath the southern profile. Based on gravity inversion, pre-Tertiary basement lies about $250 \mathrm{~m}$ beneath the anomaly on the northern profile and $400 \mathrm{~m}$ beneath the anomaly on the southern profile (Blakely and others, 1998). Taken at face value, therefore, the southern part of the magnetic unit lies above pre-Tertiary basement rocks, but the northern part is within the pre-Tertiary section. It is unlikely that pre-Tertiary basement rocks cause the anomaly, however. No aeromagnetic anomalies are observed over exposed preTertiary rocks in the immediate vicinity, and later we will show that a sharp rise in pre-Tertiary basement at Devils Hole produces no magnetic anomaly at ground level. It is more likely that the modest disagreement in depth to magnetic source, based on ground-magnetic profiles, and depth 
(A)
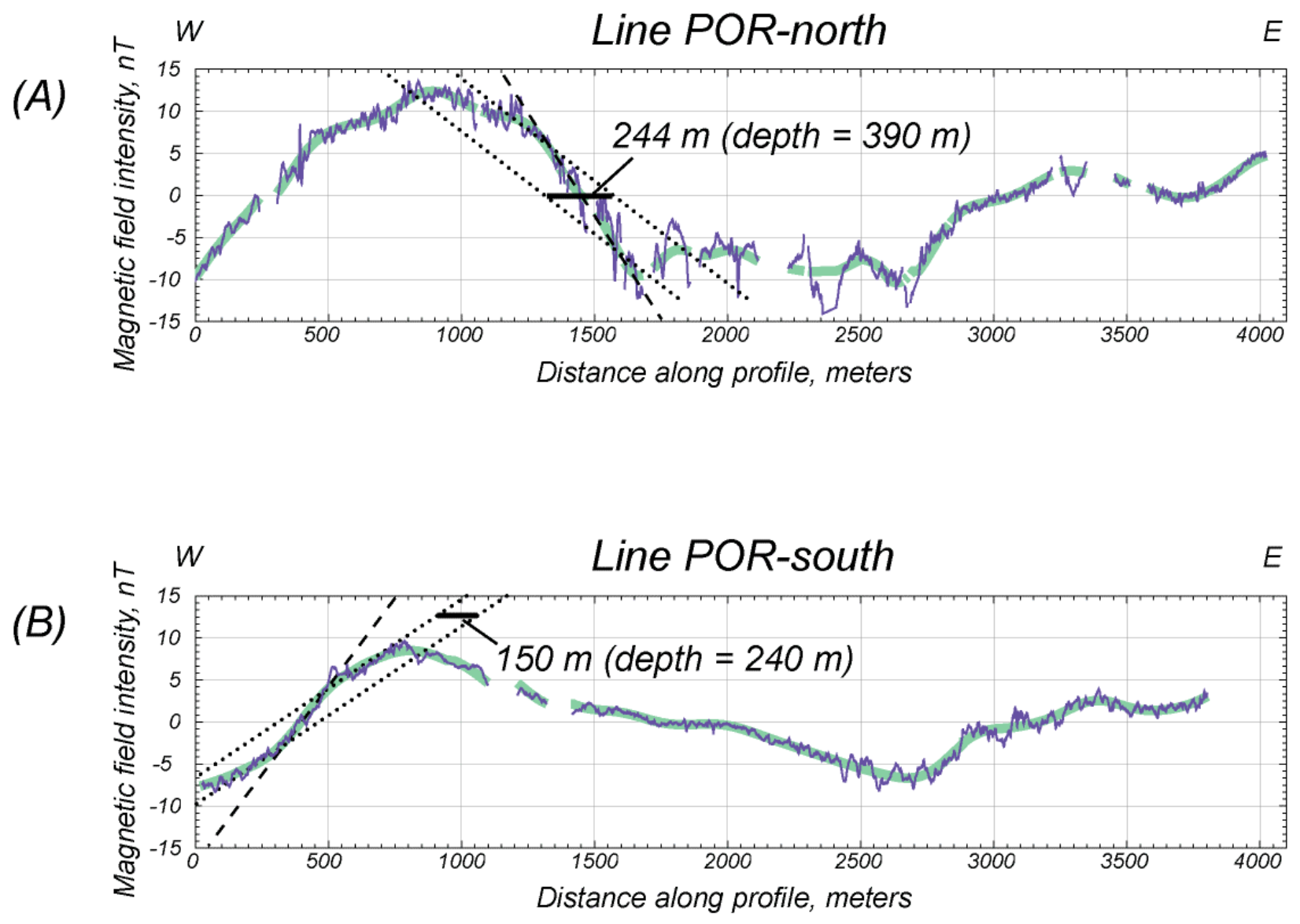

Figure 6.--Ground magnetic profiles across Point of Rocks aeromagnetic anomaly. See Figure 3 for profile locations. Thin purple lines indicate observed magnetic field intensity; wide green lines are 200-point running averages. Dashed and dotted lines were used to estimate depth to magnetic source using Peters' method (1949), as discussed in text. Dashed lines indicate maximum slope of magnetic anomaly; dotted lines have slopes equal to 0.5 maximum slope.

to pre-Tertiary basement, based on gravity inversion, reflects the approximate nature of these calculations. We conclude that the source of the anomaly near Point of Rocks Spring is caused by a magnetic unit lying near the bottom of the Cenozoic section, possibly a small sliver of Tertiary volcanic rocks. The anomaly in the northern profile has higher amplitude and a deeper source than the southern profile, suggesting that the causative body is volumetrically larger beneath the northern profile.

\section{Fairbanks Spring (profile FBS)}

A ground-magnetic profile (Fig. 3, profile FBS) was conducted along a dirt road extending from Fairbanks Spring northeastward toward the intersection of State Route 16 and U.S. Route 95. The profile is underlain by older alluvium (middle Pleistocene to late Tertiary) and spring 
deposits associated with modern or past ground-water discharge. The profile also crosses several linear, north-northwest-striking aeromagnetic anomalies (Fig. 3A). The southwestern end of the profile corresponds with a broad positive aeromagnetic anomaly with sharp northeastern margin, and the northeastern end crosses at least three low-amplitude, linear anomalies with similar strike. All of these aeromagnetic anomalies have a similar northnorthwest strike.

Ground-magnetic profile FBS (Fig. 7) reflects the same anomalies: A broad magnetic high at the southwestern end and a series of short-wavelength anomalies at the northeastern end. Individual anomalies at the northeast end are low in amplitude, approximately 10 to $30 \mathrm{nT}$ peakto-trough, but they coalesce to form a broad anomaly with significant amplitude, $85 \mathrm{nT}$ peak-totrough. We estimate the depth to the shallowest part of the magnetic source at the northeastern end to be about $592 \mathrm{~m}$.

Some alluvial deposits along the northeastern part of profile FBS have significant amounts of scoria and other volcanic rocks (Fig. 8). Collectively, these deposits have magnetic susceptibilities (Table 1, Fig. 4, site 02FS005) higher than most alluvial deposits encountered in our study, and we should consider the possibility that concentrations of similar deposits at depth cause the magnetic anomalies in profile FBS. We think this is unlikely, however. The anomalies at the northeastern end of profile FBS are within a broader region of generally highamplitude, short-wavelength aeromagnetic anomalies (Fig. 3B). This pattern is very similar to the pattern between Furnace Creek and Shoshone (Fig. 3B), where the aeromagnetic anomalies are known to be caused by exposed Tertiary volcanic rocks of the Death Valley volcanic field. It is likely that aeromagnetic anomalies northeast of Fairbanks Spring are caused by similar volcanic rocks concealed by younger alluvium and spring deposits.

Gravity inversions (Blakely and others, 1998) indicate that profile FBS crosses a saddle in the pre-Tertiary basement. The southwestern end of the profile lies over a sub-basin about $2 \mathrm{~km}$ deep, and the northeastern end lies over a second sub-basin about $0.8 \mathrm{~km}$ deep. The intervening saddle rises to $0.2 \mathrm{~m}$ depth and is located about midway along profile FBS. It is possible that some of this calculated basement topography is an artifact of non-uniform densities of overlying basin-filling sediments. In any case, the sources of the short-wavelength anomalies at the northeastern end lie above the pre-Tertiary basement.

\section{Travertine Springs (profiles TVS)}

Several short ground-magnetic profiles were conducted cross-country across a small aeromagnetic anomaly near Travertine Springs in Furnace Creek Wash (Fig. 3, profile TVS). The aeromagnetic anomaly (Fig. 3B) strikes northwest and consists of a single peak. The ground-magnetic profile (Fig. 9) reveals a more complex structure: three narrow anomalies with amplitudes of 20 to $70 \mathrm{nT}$ peak-to-trough. The sources of these anomalies lie very near the topographic surface: We estimate the depth to the most prominent anomaly at only $61 \mathrm{~m}$ below the surface.

Profile TVS is underlain by Miocene to Pliocene sedimentary rocks and modern spring deposits. Based on gravity inversions, Pre-Tertiary basement lies at depths of 600 to $700 \mathrm{~m}$ beneath profiles TVS. Thus, the source of the aeromagnetic and ground-magnetic anomalies lies within 


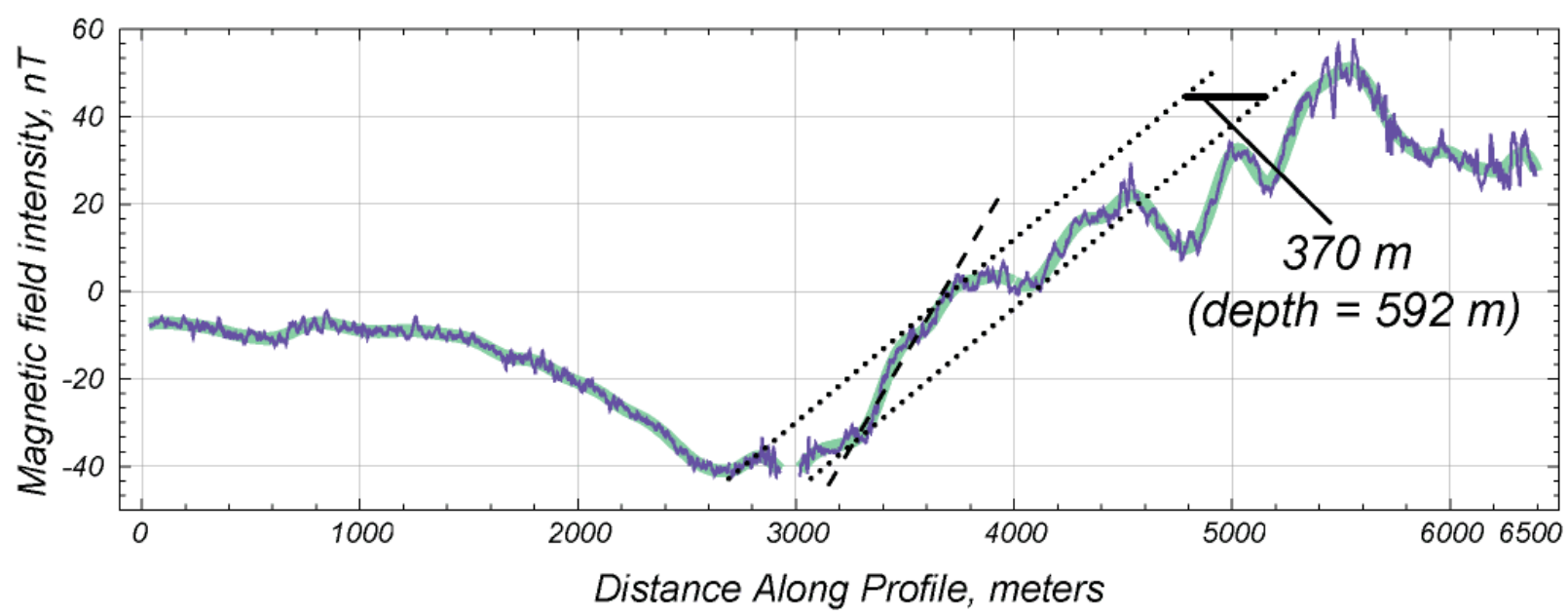

Figure 7.--Ground magnetic profiles across Fairbanks Springs aeromagnetic anomaly. See Figure 3 for profile location. Thin purple line indicates observed magnetic field intensity; wide green line is are 200point running average. Dashed and dotted lines were used to estimate depth to magnetic source using Peters' method (1949), as discussed in text. Dashed line indicates maximum slope of magnetic anomaly; dotted lines have slopes equal to 0.5 maximum slope. 


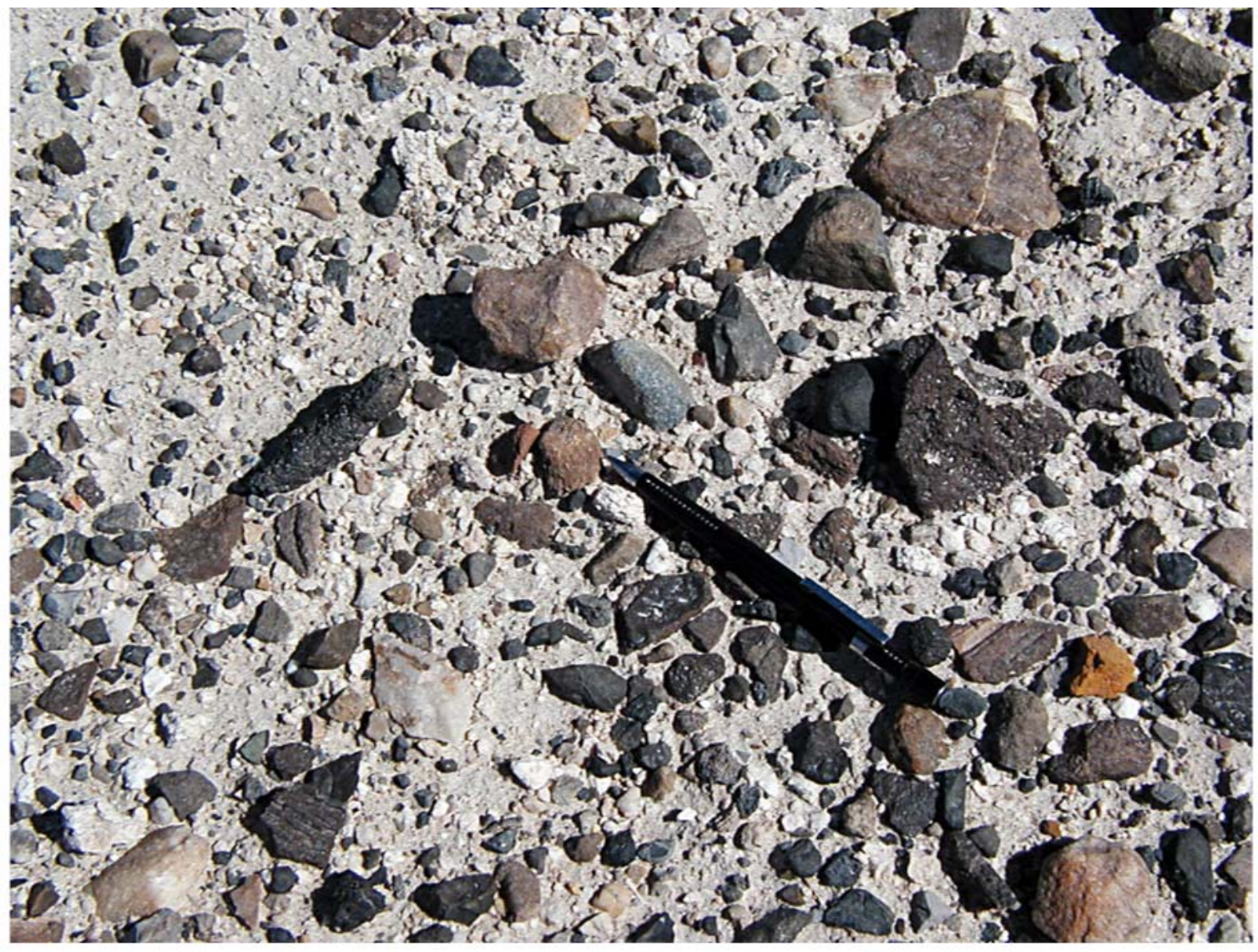

Figure 8.--Alluvial deposits along Profile FBS. Location is near site 02FS005, Fig. 4. Note abundance of scoria and other volcanic detritus. 

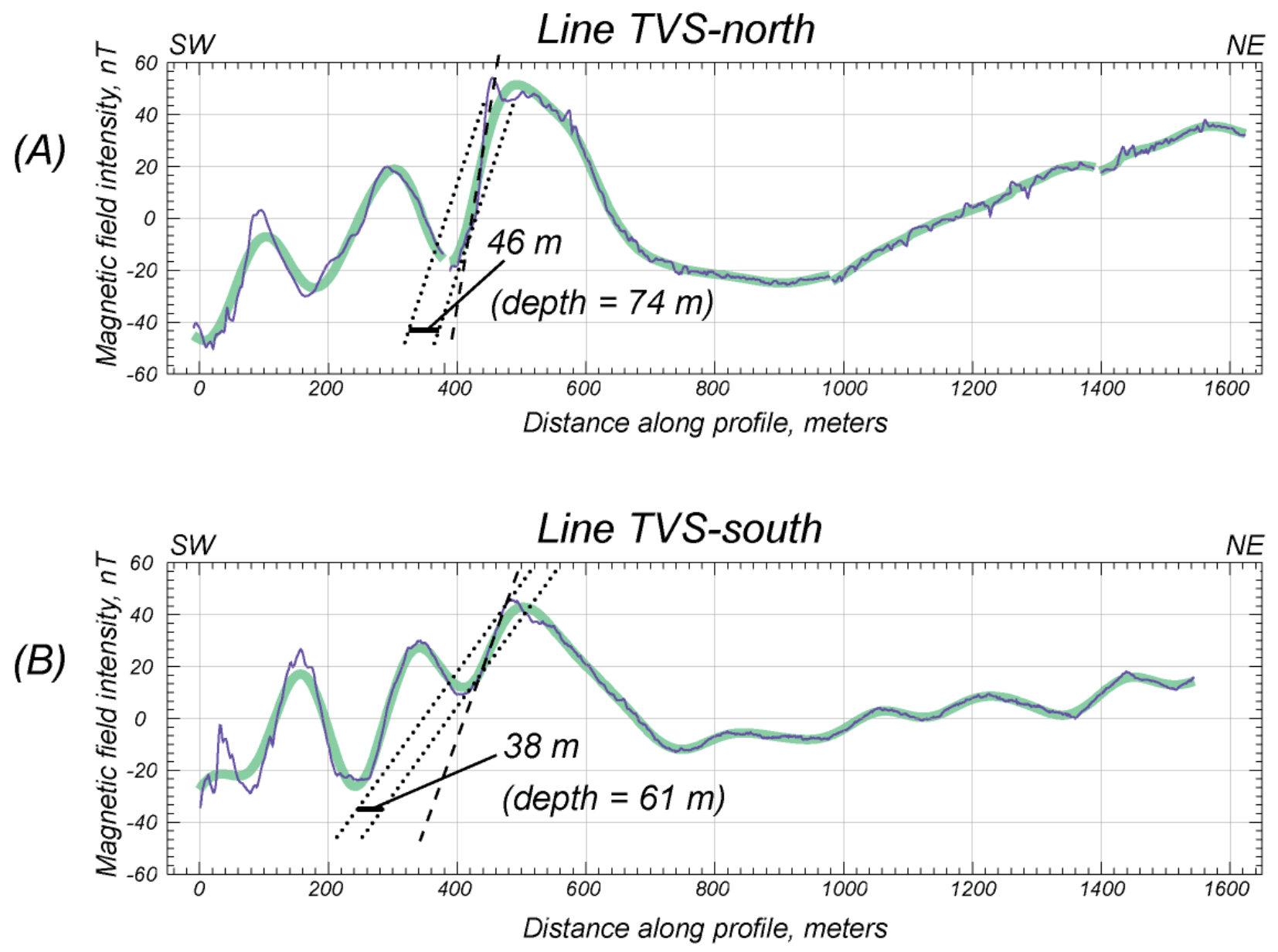

Figure 9.--Ground magnetic profiles near Travertine Springs. See Figure 3 for profile locations. Both profiles have been projected to a common straight line extending from the first to the last point of the southern profile. Thin purple lines indicate observed magnetic field intensity; wide green lines are 100point running averages. Dashed and dotted lines were used to estimate depth to magnetic source using Peters' method (1949), as discussed in text. Dashed lines indicate maximum slope of magnetic anomaly; dotted lines have slopes equal to 0.5 maximum slope.

the overlying Tertiary and Quaternary section. Fanglomerate and other alluvial deposits are exposed along the length of profile TVS, but these deposits are only weakly magnetic (Table 1, Fig. 4, sites 02TS001-003). The aeromagnetic anomaly is located near and has a character similar to the pattern of anomalies to the south, known to be caused by Tertiary volcanic rocks of the Death Valley volcanic field (Fig. 3). We conclude that the aeromagnetic anomaly at Travertine Springs is caused by a sliver of Miocene volcanic rocks now concealed by younger sediments. The narrow, linear nature of the aeromagnetic anomaly suggests that the source is bounded by northwest-striking faults. 


\section{Devils Hole (profile DVH)}

Finally, we include here a ground-magnetic profile with no pronounced magnetic anomaly in order to make an important point: pre-Tertiary rocks do not contribute appreciably to aeromagnetic anomalies in this area. The traverse was conducted along the dirt road passing by Devils Hole (Fig. 3, profile DVH), where no aeromagnetic anomalies are observed. From south to north, the route passes from relatively flat Quaternary alluvium into a narrow gap between topographically elevated areas. The surrounding hills are underlain by faulted and folded Bonanza King Formation, dolomite and limestone of Upper and Middle Cambrian age. If these rocks were significantly magnetic, the sharp rise in pre-Tertiary basement from south to north would produce a distinctive aeromagnetic anomaly at about Devils Hole and strong groundmagnetic anomalies within the topographic gap. Profile DVH (Fig. 10), however, shows only a gradual rise in amplitude, indicating very low magnetizations. This is confirmed by low magnetic susceptibilities measured at sites 02FS007 and 02FS008 (Table 1, Fig. 4). Thus, preTertiary rocks in this area do not contribute significantly to aeromagnetic anomalies.

\section{CONCLUSIONS}

A number of explanations should be considered for aeromagnetic and ground-magnetic anomalies observed over alluvium in the Amargosa Desert region. First, we can rule out preTertiary carbonate and crystalline rocks as potential magnetic sources. Although exceptions do exist (e.g., Hillhouse and Morin, 2003), such rocks typically have very low magnetizations. We have confirmed this with susceptibility measurements of and a ground-magnetic transect through exposed dolomites near Devils Hole. Moreover, the depth to the sources of the aeromagnetic and ground-magnetic anomalies place the causative magnetic bodies above the pre-Tertiary basement.

Second, it is possible that the alluvium itself is magnetic. Near Fairbanks Spring, fanglomerate exposures have significant fractions of volcanic detritus (Fig. 8) and an average magnetic susceptibility of $1.447 \times 10^{-3}$ SIU (Table 1, Fig. 4, site 02FS005). Although somewhat more magnetic than alluvium elsewhere in our study, unrealistically large volumes of these deposits would be required in order to account for the amplitudes of observed ground-magnetic anomalies.

Third, secondary mineralization, perhaps along faulted contacts, may introduce magnetic minerals into the alluvial section. Calcite veins along the highway between Furnace Creek and Death Valley Junction (Fig. 11) provide an example of what we might expect. These veins display banded iron-oxide staining, presumably secondary hematite. Hematite is only weakly magnetic (Telford and others, 1990, p. 74), as demonstrated by our measured magnetic susceptibilities (Table 1, Fig. 4, site 02CV001a). Indeed, the iron-stained veins are only slightly more magnetic than the surrounding fanglomerate deposits (Table 1, Fig. 4, site 02CV001b). 


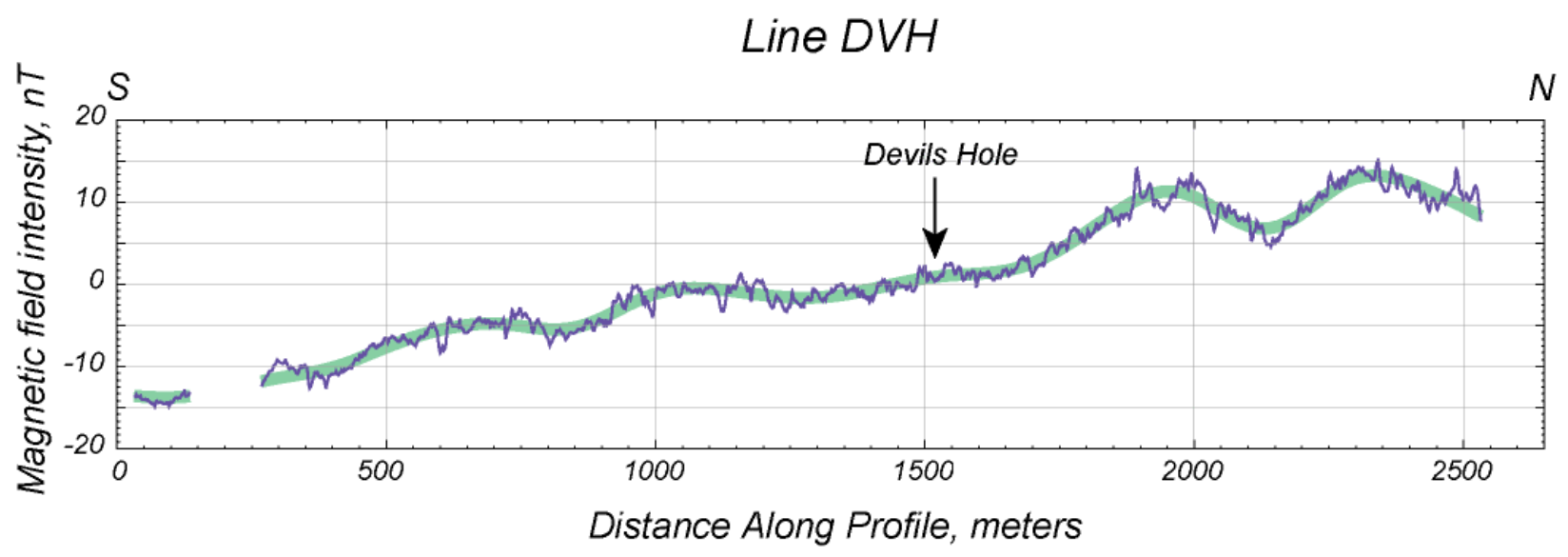

Figure 10.--Ground magnetic profile near Devils Hole. See Figure 3 for profile location. Thin purple line indicates observed magnetic field intensity; wide green line is are 200-point running average.

Fourth, the ground-magnetic and aeromagnetic anomalies over alluvium may be caused by discrete magnetic units at depth. Considering the abundance of lava flows, ash-fall tuff, and other volcanic deposits in the nearby Greenwater Range (Fig. 3), we believe Tertiary volcanic rocks of the Death Valley volcanic field are likely candidates. The linear nature of these anomalies suggests that the concealed volcanic rocks may be bounded and offset by faults.

Our study shows the utility of ground-magnetic investigations to facilitate interpretation of aeromagnetic anomalies. The 1999 and 2000 aeromagnetic surveys over Amargosa Desert and Death Valley were flown along flight lines spaced $400 \mathrm{~m}$ apart and at an altitude of $150 \mathrm{~m}$ above terrain, or as low as safely permitted. Because of steep terrain, actual flight altitudes were often significantly higher that $150 \mathrm{~m}$ above terrain. Nevertheless, our ground-magnetic transects confirm that these aeromagnetic data can resolve weakly magnetic lithologic units in the alluvial section.

\section{ACKNOWLEDGMENTS}

We are grateful to Dan Scheirer and Darcy McPhee for helpful comments and for reviews of our initial manuscript. This work was partially funded by the National Park Service under Interagency Agreement IA2380990002, Task Order 02-12. 


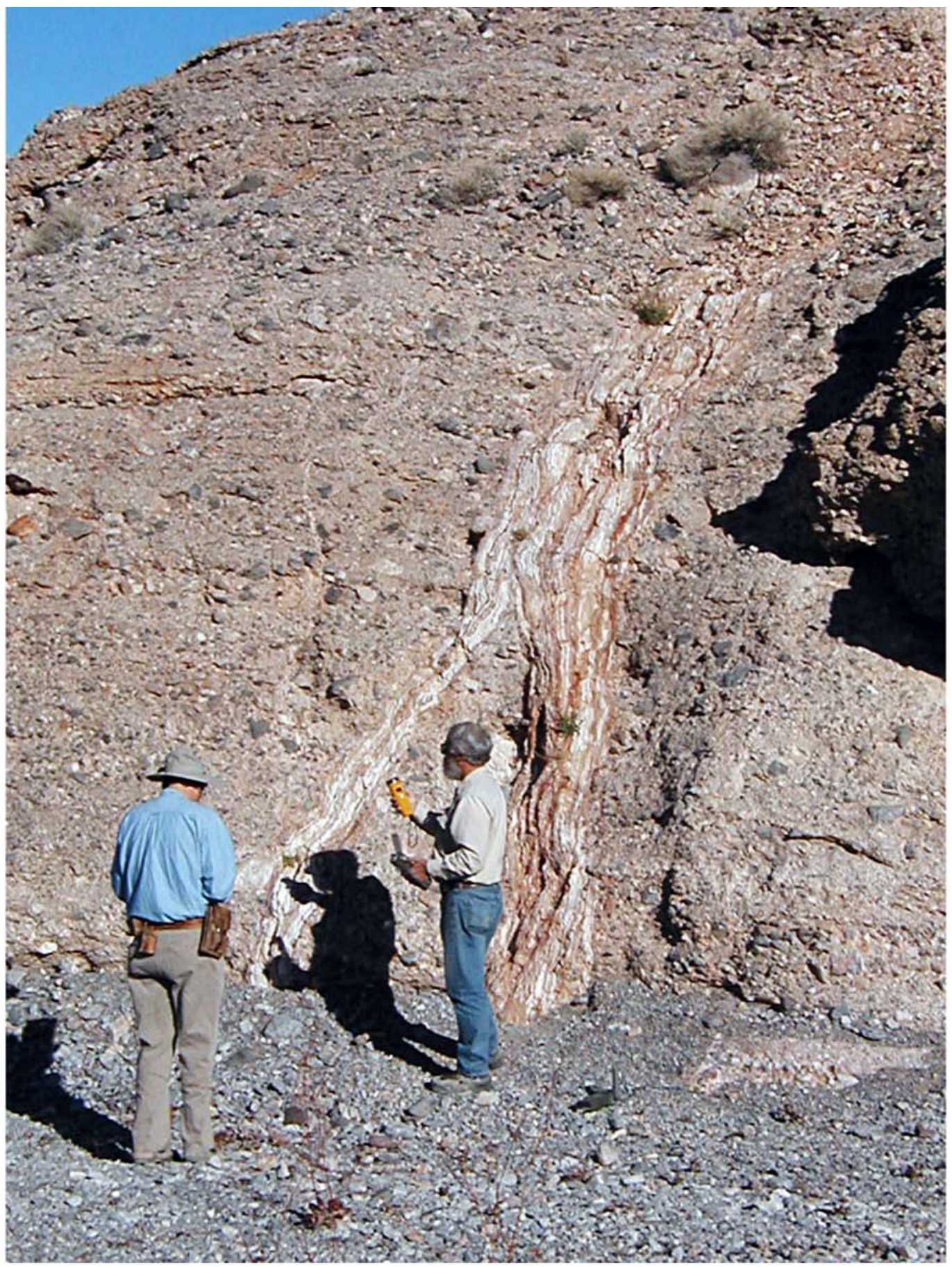

Figure 11.--Calcite veins in alluvial deposits. Photograph taken at magnetic susceptibility site $02 \mathrm{CV} 001$ (Fig. 4). Note banded iron-oxide stains within calcite veins. 


\section{REFERENCES}

Blakely, R.J., Langenheim, V.E., Ponce, D.A., and Dixon, G.L., 2000a, Aeromagnetic survey of the Amargosa Desert, Nevada and California-a tool for understanding near-surface geology and hydrology: U.S. Geological Survey Open-File Report 00-188, 32 p., 2 plates. http://geopubs.wr.usgs.gov/open-file/of00-188

Blakely, R.J., Langenheim, V.E., and Ponce, D.A., 2000b, Summary of geophysical investigations of the Death Valley regional water-flow modeling project, Nevada and California: U.S. Geological Survey Open-File Report 00-189, 31 p., 2 plates. http://geopubs.wr.usgs.gov/open-file/of00-189

Blakely, R.J., Morin, R.L., McKee, E.H., Schmidt, K.M., Langenheim, V.E., and Dixon, G.L., 1998, Three-dimensional model of Paleozoic basement beneath Amargosa Desert and Pahrump Valley, California and Nevada: Implications for tectonic evolution and water resources: U.S. Geological Survey Open-File Report 98-496, 29 p.

Burchfiel, B.C., and Stewart, J.H., 1966, "Pull-apart" origins of the central segment of Death Valley, California: Geological Society of America Bulletin, v. 77, p. 439- 442.

Connor, C.B., Stamatakos, J.A., Ferrill, D.A., Hill, B.E., Ofoegbu, G.I., Conway, F.M., Sagar, B., and Trapp, J., 2000, Geologic factors controlling patterns of small volume basaltic volcanism: Application to a volcanic hazards assessment at Yucca Mountain, Nevada: Journal of Geophysical Research, v. 105, p. 417-432.

Dettinger, M.D., 1989, Distribution of carbonate-rock aquifers in southern Nevada and the potential for their development, summary of findings, 1985-88: Program for the Study and Testing of Carbonate-Rock Aquifers in Eastern and Southern Nevada, Summary Report No. 1, U.S. Geological Survey, Desert Research Institute, and University of Nevada.

Dohrenwend, J.C., and Moring, B.C., 1993, Reconnaissance photogeologic map of late Tertiary and Quaternary faults in Nevada: Geological Society of America Abstracts with Programs, 89th Cordilleran Section Meeting and 46th Annual Rocky Mountain Section Meeting, v. 25, p. 31.

Hamilton, W.B., 1988, Detachment faulting in the Death Valley region, California and Nevada, in Carr, M.D., and Yount, J.C., eds., Geologic and hydrologic investigations of a potential nuclear waste disposal site at Yucca Mountain, southern Nevada: U.S. Geological Survey Bulletin 1790, p. 51-85.

Hillhouse, J.W., and Morin, R., 2003, Investigation of linear magnetic anomalies in the Funeral Mountains, Death Valley region, California: U.S. Geological Survey Open-File Report 03-12, $16 \mathrm{p}$.

Holm, D.K., and Wernicke, B., 1990, Black Mountains crustal section, Death Valley extended terrain, California: Geology, v. 18, p. 520-523. 
Jachens, R.C., and Moring, B.C., 1990, Maps of thickness of Cenozoic deposits and the isostatic residual gravity over basement for Nevada: U.S. Geological Survey Open-File Report 90-404, scale 1:1,000,000.

Jennings, C.W., 1977, Geologic map of California: California Division of Mines and Geology Geologic Map No. 2, scale 1:750,000.

Laczniak, R.J., Cole, J.C., Sawyer, D.A., and Trudeau, D.A., 1996, Summary of hydrogeologic controls on ground-water flow at the Nevada Test Site, Nye County, Nevada: U.S. Geological Survey Water Resources Investigations Report 96-4109, 59 p.

Lienkaemper, J.J., 1985, Quaternary fault map of California in digital format: U.S. Geological Survey Open-File Report 85-211, 14 p., magnetic tape.

McKee, E.H., 1997, Evaluation of geologic structure guiding ground water flow south and west of Frenchman Flat, Nevada Test Site: U.S. Geological Survey Open-File Report 97-734, $26 \mathrm{p}$.

Peters, L.J., 1949, The direct approach to magnetic interpretation and its practical application: Geophysics, v. 14, p. 290-320.

Ponce, D.A., Sikora, R.F., Roberts, C.W., Morin, R.L., and Halvorson, P.F., 1995, Magnetic investigations along selected high-resolution seismic traverses in the central block of Yucca Mountain, Nevada: U.S. Geological Survey Open-File Report 95-667, 23 p.

Schweickert, R.A., and Lahren, M.M., 1997, Strike-slip fault system in Amargosa Valley and Yucca Mountain, Nevada: Tectonophysics, v. 272, p. 25-41.

Stewart, J.H., 1983, Extensional tectonics in the Death Valley area, California: Transport of the Panamint Range structural block 80 km northwestward: Geology, v. 11, p. 153-157.

Stewart, J.H., and Carlson, J.E., 1978, Geologic map of Nevada: U.S. Geological Survey, scale 1:500,000.

Telford, W.M., Geldart, L.P., and Sheriff, R.E., 1990, Applied Geophysics, Second Edition: Cambridge University Press, 770 p.

Wernicke, B.P., Axen, G.J., and Snow, J.K., 1988, Basin and Range extensional tectonics near the latitude of Las Vegas, Nevada: Geological Society of America Bulletin, v. 100, p. $1738-1757$.

Winograd, I.J., and Thordarson, W., 1975, Hydrogeologic and hydrochemical framework, southcentral Great Basin, Nevada-California, with special reference to the Nevada Test Site: U.S. Geological Survey Professional Paper 712-C, 126 p. 
Workman, J.B., Menges, C.M., Page, W.R., Taylor, E.M., Ekren, E.B., Rowley, P.D., Dixon, G.L., Thompson, R.A., and Wright, L.A., 2002, Geologic map of the Death Valley ground-water model area, Nevada and California: U.S. Geological Survey Miscellaneous Field Studies MF-2381-A, 26 p. text, 2 sheets, scale 1:250,000.

Wright, L.A., 1988, Overview of the role of strike-slip and normal faulting in the Neogene history of the region northeast of Death Valley, California-Nevada, in Ellis, M.A., ed., Selected papers from the workshop, Late Cenozoic evolution of the southern Great Basin, Reno, Nevada, November 10-13, 1987, p. 1-11.

Wright, L.A., and Troxel, B.W., 1973, Shallow-fault interpretation of Basin and Range structure, southwestern Great Basin, in Dejong, K.A., and Scholten, R., eds., Gravity and tectonics: New York, John Wiley, p. 397-407. 